\title{
Rituximab in Adult Minimal Change Disease and Focal Segmental Glomerulosclerosis
}

\author{
Andreas Kronbichler $^{a} \quad$ Annette Bruchfeld ${ }^{b}$ \\ a Department of Internal Medicine IV (Nephrology and Hypertension), Medical University Innsbruck, Innsbruck,

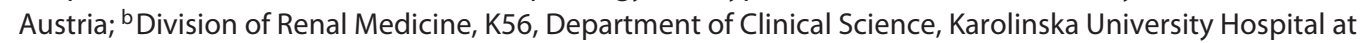 \\ Huddinge, Interventions and Technology (CLINTEC), Karolinska Institutet, Stockholm, Sweden
}

\section{Key Words}

Rituximab - Minimal change disease $\cdot$ Focal segmental glomerulosclerosis · Nephrotic syndrome

\begin{abstract}
Treatment of nephrotic syndrome due to minimal change disease and focal segmental glomerulosclerosis remains a challenge since steroid dependence, steroid resistance and a relapsing disease course exhibits a high cumulative steroid dosage. The necessity of using alternative steroid-sparing immunosuppressive agents with potential toxic side effects also restricts their long-term use. Rituximab, a monoclonal antibody targeting CD20, has been increasingly used in the therapy of difficult-to-treat nephrotic syndrome. A clinical response has been shown for patients with steroid-dependent or frequently relapsing nephrotic syndrome, whereas the benefit seems to be limited in steroid-resistant patients, especially those with underlying focal segmental glomerulosclerosis. No potentially life-threatening adverse events have been observed in the treatment of adult minimal change disease and focal segmental glomerulosclerosis following rituximab administration. Since most reports are retrospective and evidence of efficacy is derived from small
\end{abstract}

case series, more prospective trials in a controlled, randomized manner are highly desirable to delineate the use of rituximab or other $\mathrm{B}$ cell-depleting agents in steroid-dependent, frequently relapsing or steroid-resistant patients.

(c) 2014 S. Karger AG, Basel

\section{Introduction}

Nephrotic syndrome due to underlying minimal change disease (MCD) or focal segmental glomerulosclerosis (FSGS) remains a therapeutic challenge for the treating physician. A high proportion of initial steroidresponsive patients develop a steroid-dependent or steroid-resistant disease course necessitating the use of a high cumulative dose of steroids. As steroids per se exhibit an unfavorable spectrum of side effects, second- or third-line immunosuppressive treatment options such as calcineurin inhibitors, mycophenolate mofetil or al-

Biologic Treatment in Glomerular Disease D. Jayne, Cambridge

V. Tesar, Prague

\section{KARGER}

E-Mail karger@karger.com

www.karger.com/nec
(C) 2014 S. Karger AG, Basel

$1660-2110 / 14 / 1284-0277 \$ 39.50 / 0$ 
kylating agents are often required in these patients to spare and reduce the side effects of steroids $[1,2]$. There are, however, limitations to these alternative agents due to toxicity attributable to their use. Novel agents with a good efficacy and safety profile are therefore highly desirable. Rituximab (RTX), a chimeric monoclonal antibody directed against CD20-bearing cells, has emerged as an option in the treatment of MCD or FSGS.

\section{Targeting CD20/RTX Mode of Action: Pathophysiologic Considerations}

Several mechanisms have been discussed and proposed for RTX efficacy in immune-mediated diseases. Depletion of peripheral, circulating CD19+/CD20+ B cells is usually achieved by a single infusion of RTX [3]. Since autoimmune diseases such as rheumatoid arthritis or idiopathic thrombocytopenic purpura, diseases predominantly mediated by T-helper cells, usually respond to a B cell-depleting therapy with RTX, it was proposed that targeting CD20 may at least partially affect autoreactive $\mathrm{T}$ cells as well. Within the immunological synapse, inflammatory cells and phagocytes may remove anti-CD20 opsonized B cells and in a similar fashion autoreactive $\mathrm{T}$ cells that interact with autoantigen-presenting B cells. Moreover, RTX therapy leads to antibodydependent cell-mediated cytotoxicity, phagocytosis and complement-mediated cytotoxicity. The latter, complement activation, results in formation of the membraneattacking complex-killing B cells [4]. Besides the immunologic alterations executed by B cell depletion, direct effects of RTX on the podocyte cytoskeleton have been demonstrated [5]. In patients developing recurrence of FSGS after kidney transplantation, the number of sphingomyelin-phosphodiesterase acid-like 3b (SMPDL-3b)positive podocytes in postperfusion biopsies was reduced. In addition, reduction in the amount of acidsphingomyelinase (ASMase) protein was observed in podocytes treated with FSGS sera. Treatment with RTX partially prevented SMPDL-3b and ASMase downregulation in podocytes treated with patient sera after recurrence of FSGS [5]. Podocyte expression of B7-1 (CD80) and disorganized integrin function has been implicated in the development of proteinuria. Novel strategies to target B7-1 have recently been reported to abrogate proteinuria in recurrent FSGS [6]. Reports studying podocyte B7-1 in kidney biopsies prior to and after RTX treatment as well as potential stabilization of the integrin function and in vitro experiments are lacking.

\section{Efficacy of RTX in Adult MCD and FSGS}

B cell-depleting therapy with RTX is increasingly being used in MCD and FSGS. The clinical data of the most important studies are depicted in tables 1 and 2. In steroid-resistant FSGS, a retrospective analysis of a Spanish registry revealed achievement of partial remission in 2 patients with a more intense RTX treatment regimen (4 consecutive weekly and 2 additional infusions after six months as well as 8 consecutive weekly infusions, respectively), a transient response twice after therapy in 1 patient and no response after RTX therapy in 5 patients. At baseline, all patients exhibited severe nephrotic range proteinuria and were on background immunosuppression [7]. A prospective study with a short follow-up period of 6 months demonstrated good efficacy with complete remission following a single dose of RTX in most MCD patients, whereas 2 out of 4 patients with FSGS did not respond. However, $1 \mathrm{MCD}$ patient in this cohort relapsed at the time of last follow-up [8]. Kong et al. [9] reported a beneficial effect of RTX therapy in diverse glomerulonephritis, including patients with advanced decline in kidney function and 1 elderly patient. A large retrospective analysis from a French cohort showed a relapse-free disease course following RTX in 11 out of 17 patients with MCD. Moreover, the disease course was positively influenced by the presence of remission prior to RTX administration. A significant decline of steroids used was shown in this cohort as well [10]. Takei et al. [11] published a prospective trial including 25 patients with MCD. The patients received a single dose of RTX (max. $500 \mathrm{mg}$ ) at baseline and then a fixed regimen after 6 months. After 12 months of follow-up, all but 1 patient achieved complete remission, whereas 4 relapses occurred during the study period. Notably, only 8 out of 25 patients had nephrotic range proteinuria at baseline. In their retrospective analysis, Bruchfeld et al. [12] observed good efficacy after RTX therapy with achievement of remission in 15 out of 16 MCD patients. In addition, the majority of patients remained relapse-free during a follow-up period of at least 12 months. More recently, a prospective study from Italy examined RTX efficacy to reduce relapses after achievement of remission. All adult patients remained in remission, whereas the rate of relapses and steroid use could be reduced significantly [3]. Another prospective study revealed a good response after RTX in patients with steroid-resistant forms of MCD and FSGS, although important clinical information is missing in this instead of that report [13]. We performed an analysis of the reported data on steroid-dependent and mul- 
Table 1. Patient characteristics

\begin{tabular}{|c|c|c|c|c|c|c|c|c|}
\hline First author & Disease & Previous therapies & $\begin{array}{l}\text { Proteinuria } \\
\text { (at the time of } \\
\text { RTX) }\end{array}$ & $\begin{array}{l}\text { Proteinuria } \\
\text { (at the time of } \\
\text { last follow-up) }\end{array}$ & $\begin{array}{l}\text { Follow-up } \\
\text { time, } \\
\text { months }\end{array}$ & $\begin{array}{l}\text { Relapses } \\
\text { after RTX }\end{array}$ & $\begin{array}{l}\text { Steroids prior } \\
\text { RTX }\end{array}$ & $\begin{array}{l}\text { Steroids at } \\
12 \text { months } \\
\text { follow-up }\end{array}$ \\
\hline Sugiura [8] & $\begin{array}{l}\text { MCD (10), } \\
\text { FSGS (4) }\end{array}$ & $\begin{array}{l}\text { MMF (2), CSA (8), } \\
\text { MZ (2) }\end{array}$ & $\begin{array}{l}\text { CR (4), } \\
\text { PR (2), NRP (8) }\end{array}$ & $\begin{array}{l}\text { CR (11), } \\
\text { NR (3) }\end{array}$ & 6 & 1 relapse (1) & $\begin{array}{l}21 \mathrm{mg} / \text { day } \\
(\mathrm{MCD}), 23.8 \\
\mathrm{mg} / \text { day (FSGS) }\end{array}$ & $\begin{array}{l}11.5 \mathrm{mg} / \text { day } \\
(\mathrm{MCD}), 10 \mathrm{mg} / \\
\text { day (FSGS) }\end{array}$ \\
\hline Kong [9] & $\begin{array}{l}\text { MCD (7), } \\
\text { FSGS (4) }\end{array}$ & $\begin{array}{l}\text { MMF (4), AZA (1), } \\
\text { CSA (4), CPA (5), } \\
\text { plasma exchange (1), } \\
\text { IL-5 receptor } \\
\text { antagonist (1) }\end{array}$ & not reported ${ }^{a}$ & $\begin{array}{l}\text { CR (7), } \\
\text { PR (3), } \\
\text { NR (1) }\end{array}$ & $11.8-49.3$ & $\begin{array}{l}1 \text { relapse }(2), \\
2 \text { relapses }(1)\end{array}$ & not reported & $\begin{array}{l}\text { at least } 50 \% \\
\text { reduction after } \\
3 \text { months }\end{array}$ \\
\hline Takei [11] & $\operatorname{MCD}(25)$ & $\begin{array}{l}\operatorname{MMF}(3), \text { CSA (20), } \\
\operatorname{MZ~(5)~}\end{array}$ & $\begin{array}{l}\mathrm{CR}(9), \mathrm{PR}(8), \\
\mathrm{NRP}(6)\end{array}$ & $\begin{array}{l}\text { CR (24), } \\
\text { NR (1) }\end{array}$ & 12 & 1 relapse (4) & $26.4 \mathrm{mg} /$ day & $1.1 \mathrm{mg} /$ day \\
\hline Bruchfeld [12] & $\operatorname{MCD}(16)$ & $\begin{array}{l}\text { Tac (1), MMF (4), } \\
\text { AZA (2), CSA (3), } \\
\text { CPA (5), levamisole } \\
\text { (2), LDL-apheresis } \\
\text { (1), leukeran (1) }\end{array}$ & $\begin{array}{l}\mathrm{CR}(2), \mathrm{PR}(5) \\
\mathrm{NPR}(9)\end{array}$ & $\begin{array}{l}\text { CR (13), } \\
\operatorname{PR}(2), \\
\text { NR (1) }\end{array}$ & $12-70$ & $\begin{array}{l}1 \text { relapse }(6), \\
2 \text { relapses }(1)\end{array}$ & $25.6 \mathrm{mg} /$ day & $2.3 \mathrm{mg} /$ day \\
\hline Ruggenenti [3] & $\begin{array}{l}\text { MCD (15), } \\
\text { FSGS (5), }\end{array}$ & $\begin{array}{l}\text { MMF (9), AZA (1), } \\
\text { CSA (9), CPA (7) }\end{array}$ & CR or PR (20) & CR or PR (20) & 12 & $\begin{array}{l}\text { at least } \\
1 \text { relapse (8) }\end{array}$ & $\begin{array}{l}0.27 \mathrm{mg} / \mathrm{kg} \text { body } \\
\text { weight }^{\mathrm{b}}\end{array}$ & $\begin{array}{l}0 \mathrm{mg} / \mathrm{kg} \text { body } \\
\text { weight }^{\mathrm{b}}\end{array}$ \\
\hline
\end{tabular}

The number of patients is shown in parenthesis. Tac = Tacrolimus; $\mathrm{MMF}=$ mycophenolate mofetil; $\mathrm{CSA}=$ cyclosporine $\mathrm{A} ; \mathrm{CPA}=$ cyclophos phamide; $\mathrm{AZA}=$ azathioprine; $\mathrm{MZ}=$ mizoribine $\mathrm{LDL}=$ low-density lipoprotein; $\mathrm{CR}=$ complete remission; $\mathrm{PR}=$ partial remission; $\mathrm{NRP}=$ nephrotic range proteinuria; $\mathrm{NR}=$ no remission. ${ }^{\text {a }}$ Proteinuria not quantified in this report; overall, patients with MCD had a nephrotic range proteinuria, whereas patients with FSGS had a baseline proteinuria just over $2 \mathrm{~g} /$ day. ${ }^{\mathrm{b}} 10$ chil- dren with steroid-dependent or frequently relapsing nephrotic syndrome were included in this prospective study as well; reduction of steroid dosage from the time point of initiation of RTX as well as after 12 months was calculated irrespective of age. ${ }^{c}$ In this prospective study, El-Reshaid et al. included children (defined as age below 14 years, a total of 11 patients) and adults (age above 14 years, a total of 39 patients). tirelapsing MCD and FSGS including 86 patients to elucidate factors influencing therapeutic responses towards RTX. In this study, we observed a significant reduction of annual relapses after RTX therapy. In addition, the number of immunosuppressants could be significantly reduced following therapy. However, there was an association between a high number of immunosuppressive agents used before RTX and an increased risk of relapse after therapy [14].

\section{Adverse Event Spectrum of RTX Treatment}

Complications of RTX therapy are generally divided into acute and late-onset adverse events. No severe side effects such as progressive multifocal leukoencephalopathy or Pneumocystis jirovecii pneumonia have been observed in adult patients with underlying MCD or FSGS treated with RTX. In their retrospective analysis treating several glomerulonephritis patients, Kong et al. [9] ob- 
Table 2. Mode of RTX administration, the time to first relapse after RTX as well as information about B cell repletion prior to relapse and the study design of the reports

\begin{tabular}{|c|c|c|c|c|c|c|}
\hline First author & $\begin{array}{l}\text { Characteristics of } \\
\text { nephrotic syndrome, } \\
\text { SD/MR or SR }\end{array}$ & Administration of RTX & $\begin{array}{l}\text { Time to first relapse, } \\
\text { months }\end{array}$ & $\begin{array}{l}\text { B cell repletion } \\
\text { during relapse, } \\
\text { yes } / \text { no }\end{array}$ & $\begin{array}{l}\text { B cell repletion, } \\
\text { no clinical relapse }\end{array}$ & $\begin{array}{l}\text { Study } \\
\text { design }\end{array}$ \\
\hline Sugiura [8] & SD/MR (4), SR (10) & $\begin{array}{l}1 \times 375 \mathrm{mg} / \mathrm{m}^{2} \\
(\max .500 \mathrm{mg})(14)\end{array}$ & $3(1)$ & not reported & not reported & pro \\
\hline Kong [9] & $\begin{array}{l}\mathrm{SD} / \mathrm{MR}(6), \mathrm{SR}(3) \text {, } \\
\text { other causes of RTX } \\
\text { administration in } 2 \text { cases }\end{array}$ & $\begin{array}{l}1 \times 500 \mathrm{mg}(4), 1 \times 600 \mathrm{mg} \mathrm{(3)}, \\
1 \times 700 \mathrm{mg}(1), 2 \times 700 \mathrm{mg}(2), \\
4 \times 500 \mathrm{mg}(1), 4 \times 600 \mathrm{mg}(1)\end{array}$ & not reported & not reported & not reported & retro \\
\hline $\begin{array}{l}\text { Munyentwali } \\
{[10]}\end{array}$ & SD/MR (17) & $\begin{array}{l}1 \times 375 \mathrm{mg} / \mathrm{m}^{2}(1) \\
2 \times 375 \mathrm{mg} / \mathrm{m}^{2}(7), 3 \times 375 \mathrm{mg} / \mathrm{m}^{2} \\
(4), 4 \times 375 \mathrm{mg} / \mathrm{m}^{2}(3) \\
2 \times 1,000 \mathrm{mg}(2)\end{array}$ & $4.8-16.3(6)$ & yes (5), no (1) & $\begin{array}{l}4 \text { patients, no } \\
\text { information provided } \\
\text { for the additional } 7 \\
\text { patients }\end{array}$ & retro \\
\hline Bruchfeld [12] & SD/MR (15), SR (1) & $\begin{array}{l}3 \times 375 \mathrm{mg} / \mathrm{m}^{2}(1) \\
4 \times 375 \mathrm{mg} / \mathrm{m}^{2}(4) \\
2 \times 500 \mathrm{mg}(8), 2 \times 1,000 \mathrm{mg} \mathrm{(3)}\end{array}$ & $9-28(7)$ & $\begin{array}{l}\text { yes (5), not } \\
\text { examined (2) }\end{array}$ & not examined & retro \\
\hline Ruggenenti [3] & SD/MR (20) & $\begin{array}{l}1 \times 375 \mathrm{mg} / \mathrm{m}^{2} \text { or } \\
2 \times 375 \mathrm{mg} / \mathrm{m}^{2}(20)\end{array}$ & $\begin{array}{l}\text { early relapse } \mathrm{a}^{\mathrm{a}} \text { within } \\
1 \text { month after RTX } \\
\text { (4), } 11 \text { further relapses } \\
\text { within } 12 \text { month }\end{array}$ & not reported ${ }^{\mathrm{a}}$ & $\begin{array}{l}15 \text { patients relapse-free } \\
\text { (at least a high } \\
\text { proportion with } \\
\text { repletion) }\end{array}$ & pro \\
\hline $\begin{array}{l}\text { El-Reshaid }{ }^{\mathrm{b}} \\
{[13]}\end{array}$ & SR (50) & $4 \times 375 \mathrm{mg} / \mathrm{m}^{2}$ & $\begin{array}{l}2 \text { relapses between } \\
\text { month } 8 \text { and } 12 \\
\text { (MCD population) }\end{array}$ & not reported ${ }^{b}$ & $\begin{array}{l}29 \text { patients relapse-free } \\
(\mathrm{MCD}) \text {, all with B cell } \\
\text { repletion }\end{array}$ & pro \\
\hline
\end{tabular}

$\mathrm{SD}=$ Steroid dependent; $\mathrm{SR}=$ steroid resistant; retro = retrospective; pro = prospective ${ }^{\text {a }}$ Ten children with steroid-dependent or frequently relapsing nephrotic syndrome were included in this prospective study as well; the total number of relapses reported in this prospective trial was not divided in adults and children. ${ }^{\mathrm{b}}$ In this prospective study, El-Reshaid et al. included children (defined as age below 14 years, a total of 11 patients) and adults (age above 14 years, a total of 39 patients).

served infusion reactions, such as skin rash, hypotension, bradycardia and body ache which were self-limiting, whereas 1 patient presented with bronchopneumonia 2 months after RTX. However, a retrospective analysis of patients with steroid-dependent MCD revealed no adverse events [10]. A prospective study from Japan revealed mild infusion reactions such as cough and hiccough, and an exanthema as predominant complications, whereas 1 patient developed mild leukopenia related to RTX during follow-up [11]. Bruchfeld et al. [12] reported 2 patients suffering from transient hypotension and 1 patient with itchy and red eyes. In their prospective study, Ruggenenti et al. [3] observed no immediate side effects, whereas infectious complications such as gastroenteritis, varicella or flu-like syndrome, and noninfectious complications like seizures or melanoma in situ were reported. All patients received concomitant immunosuppressive medication at the time of side-effect onset. In a prospective study treating diverse glomerulonephritis, 5 patients did not tolerate RTX and were excluded from the study [13]. Among the included patients, infusion-related symptoms were frequent (itching, hypotension or bronchospasm). Moreover, 1 patient had bloody diarrhea 2 months after RTX. Life-threatening adverse events have been observed in children with idiopathic nephrotic syndrome. Pneumocystis jirovecii pneumonia has been reported in a case with steroid-dependent nephrotic syndrome with concomitant steroid 
and cyclosporine A therapy [15]. Another case with steroid-dependent nephrotic syndrome without additional immunosuppression presented with enterovirus-associated myocarditis necessitating heart transplantation [16]. Administration of RTX led to a progressive and sustained decrease in the immunoglobulin $\mathrm{G}$ and immunoglobulin $\mathrm{M}$ levels in this patient. Moreover, it was recently shown that antibody response following Streptococcus pneumoniae and Haemophilus influenzae type b vaccination was impaired following RTX in patients with idiopathic thrombocytopenic purpura [17].

\section{The Role of B Cell Repletion in Assessing the Risk of a Relapse}

The role of $\mathrm{B}$ cell recovery in predicting the risk of a relapse is unclear. Early reports have indicated that in childhood nephrotic syndrome relapses occurred while B cell recovery was already present 7-17 months after the first RTX treatment [18]. However, a recent report suggested that repletion of CD19 was not necessarily accompanied by an increased relapse risk. In this cohort, a high proportion of patients remained relapse free during a median follow-up time of 17.4 months, although B cell recovery was definitive present in all patients [19]. The rate of $B$ cell repletion in adult patients has not been reported consistently. Table 2 summarizes the most important studies with special emphasis on relapse during B cell repletion and relapse-free follow up despite B cell recovery. Taken together, it may be questioned whether monitoring $B$ cell depletion is appropriate to evaluate the risk of relapse or not. In any case, B cell repletion is not likely to prompt therapeutic consequences unless the level of proteinuria indicates a clinical relapse.

\section{Discussion}

Clinical observations have shown the efficacy of RTX in patients with steroid-dependent nephrotic syndrome and underlying MCD and FSGS, although the latter is underrepresented in the published reports. In most studies, the use of concomitant immunosuppressive medication could be tapered and finally withdrawn in the majority of patients. In addition, most studies have shown a convincing reduction of relapses when compared to the period prior to RTX therapy. Moreover, a high number of immunosuppressants used prior to RTX revealed a higher risk of relapse in a recent analysis of reported ex- perience. This finding may be attributable to a more severe disease course entailing more immunosuppressive strategies [14]. Steroid-resistant forms of MCD and FSGS are underrepresented so far. In their retrospective analysis of adult steroid-resistant FSGS cases with multiple immunosuppressive pretreatments, FernandezFresnedo et al. [7] observed no response following administration of B cell-depleting therapy in a majority of patients. This finding was suggested to be at least partially explained by an increased urinary loss of RTX in patients with nephrotic range proteinuria. Furthermore, RTX-treated patients with idiopathic membranous nephropathy exhibited lower serum concentrations of RTX compared to patients with rheumatoid arthritis with a considerably lower terminal half-life [20]. It has been demonstrated that patients with a baseline proteinuria $<1 \mathrm{~g}$ /day tended to have sustained relapse-free remission compared to patients without remission at the time of RTX administration [10].

The spectrum of adverse events of RTX treatment in adult MCD and FSGS is favorable. No life-threatening adverse event has been reported in the literature so far. In addition to single RTX therapy, a number of patients have received RTX in a more protocolled manner despite clinical remission due to $B$ cell repletion $[11,12]$. Prolonged RTX therapy may, however, lead to pronounced hypogammaglobulinemia, increasing the risk of serious infections as well as development of human antichimeric antibodies directed against RTX, leading to a hypersensitivity reaction or inefficacy [21].

Besides RTX, the efficacy of a novel B cell depleting agent, ofatumumab, has been reported more recently. Ofatumumab is a fully human monoclonal antibody for the $\mathrm{CD} 20$ protein. Abrogation of severe nephrotic range proteinuria was observed in 5 children with RTX-resistant nephrotic syndrome. Long-term remission was observed in all 5 patients reported in this preliminary observation [22]. Moreover, belimumab, a monoclonal antibody inhibiting the B cell-stimulating factor, is currently being tested in idiopathic membranous nephropathy [23]. Abatacept, a costimulatory blocking agent, has been successfully used in 4 patients with recurrent FSGS irresponsive to RTX and 1 patient with native FSGS [6].

Taken together, the published data suggest efficacy of RTX in steroid-dependent and relapsing nephrotic syndrome with underlying MCD and FSGS, although the latter is underrepresented in these reports. More clinical trials in a prospective manner including a higher number of patients are highly desirable to confirm the value of RTX or other biological agents as a potential treatment option. 


\section{References}

$>1$ Hogan J, Radhakrishnan J: The treatment of minimal change disease in adults. J Am Soc Nephrol 2013;24:702-711.

$\checkmark 2$ Ponticelli C, Graziani G: Current and emerging treatments for idiopathic focal and segmental glomerulosclerosis in adults. Expert Rev Clin Immunol 2013;9:251-261.

>3 Ruggenenti P, Ruggiero B, Cravedi P, Vivarelli M, Massella L, Marasa M, et al: Rituximab in steroid-dependent or frequently relapsing idiopathic nephrotic syndrome. J Am Soc Nephrol 2014;25:850-863.

$\checkmark 4$ Datta SK: Anti-CD20 antibody is an efficient therapeutic tool for the selective removal of autoreactive T cells. Nat Clin Pract Rheumatol 2009;5:80-82.

$\checkmark 5$ Fornoni A, Sageshima J, Wei C, MerscherGomez S, Aguillon-Prada R, Jauregui AN, et al: Rituximab targets podocytes in recurrent focal segmental glomerulosclerosis. Sci Transl Med 2011;3:85ra46.

6 Yu CC, Fornoni A, Weins A, Hakroush S, Maiguel D, Sageshima J, et al: Abatacept in B7-1-positive proteinuric kidney disease. N Engl J Med 2013;369:2416-2423.

$>7$ Fernandez-Fresnedo G, Segarra A, Gonzalez E, Alexandru S, Delgado R, Ramos N, et al: Rituximab treatment of adult patients with steroid-resistant focal segmental glomerulosclerosis. Clin J Am Soc Nephrol 2009;4: 1317-1323.

$>8$ Sugiura H, Takei T, Itabashi M, Tsukada M, Moriyama T, Kojima C, et al: Effect of singledose rituximab on primary glomerular diseases. Nephron Clin Pract 2011;117:c98-c105.
$>9$ Kong WY, Swaminathan R, Irish A: Our experience with rituximab therapy for adult-onset primary glomerulonephritis and review of literature. Int Urol Nephrol 2013;45:795-802.

10 Munyentwali H, Bouachi K, Audard V, Remy P, Lang P, Mojaat R, et al: Rituximab is an efficient and safe treatment in adults with steroid-dependent minimal change disease. Kidney Int 2013;83:511-516.

11 Takei T, Itabashi M, Moriyama T, Kojima C, Shiohira S, Shimizu A, et al: Effect of singledose rituximab on steroid-dependent minimal-change nephrotic syndrome in adults. Nephrol Dial Transplant 2013;28:1225-1232.

12 Bruchfeld A, Benedek S, Hilderman M, Medin C, Snaedal-Jonsdottir S, Korkeila M: Rituximab for minimal change disease in adults: long-term follow-up. Nephrol Dial Transplant 2014;29:851-856.

13 El-Reshaid K, Sallam HT, Hakim AA, Al-Attiyah R: Rituximab in treatment of idiopathic glomerulopathy. Saudi J Kidney Dis Transpl 2012;23:973-978.

14 Kronbichler A, Kerschbaum J, FernandezFresnedo G, Hoxha E, Kurschat CE, Busch M, et al: Rituximab treatment for relapsing minimal change disease and focal segmental glomerulosclerosis: a systematic review. Am J Nephrol 2014;39:322-330.

15 Czarniak P, Zaluska-Lesniewska I, Zagozdzon I, Zurowska A: Difficulties in diagnosing severe Pneumocystis jiroveci pneumonia after rituximab therapy for steroid-dependent nephrotic syndrome. Pediatr Nephrol 2013;28: 987-988.

16 Sellier-Leclerc AL, Belli E, Guerin V, Dorfmüller P, Deschenes G: Fulminant viral myocarditis after rituximab therapy in pediatric nephrotic syndrome. Pediatr Nephrol 2013; 28:1875-1879.
17 Nazi I, Kelton JG, Larche M, Snider DP, Heddle NM, Crowther MA, et al: The effect of rituximab on vaccine responses in patients with immune thrombocytopenia. Blood 2013; 122:1946-1953.

18 Guigonis V, Dallocchio A, Baudouin V, Dehennault M, Hachon-Le Camus C, Afanetti $\mathrm{M}$, et al: Rituximab treatment for severe steroid- or cyclosporine-dependent nephrotic syndrome: a multicentric series of 22 cases. Pediatr Nephrol 2008;23:1269-1279.

19 Sellier-Leclerc AL, Baudouin V, Kwon T, Macher MA, Guerin V, Lapillonne H, et al: Rituximab in steroid-dependent idiopathic nephrotic syndrome in childhood - follow-up after CD19 recovery. Nephrol Dial Transplant 2012;27:1083-1089.

-20 Fervenza FC, Abraham RS, Erickson SB, Irazabal MV, Eirin A, Specks U, et al: Rituximab therapy in idiopathic membranous nephropathy: a 2-year study. Clin J Am Soc Nephrol 2010;5:2188-2198.

21 Gottenberg JE, Ravaud P, Bardin T, Cacoub P, Cantagrel A, Combe B, et al: Risk factors for severe infections in patients with rheumatoid arthritis treated with rituximab in the autoimmunity and rituximab registry. Arthritis Rheum 2010;62:2625-2632.

$\checkmark 22$ Basu B: Ofatumumab for rituximab-resistant nephrotic syndrome. N Engl J Med 2014;370: 1268-1270.

23 http://clinicaltrials.gov/ct2/show/NCT016104 92?term=belimumab+membranous+nephrop athy\&rank=2. NLM identifier: NCT01610492. 